\title{
THE SAMARITAN DIASPORA IN ANTIQUITY
}

\begin{abstract}
Summary: This paper discusses the problems and state of the Samaritan diaspora situation in Antiquity. It was difficult for contemporaries to distinguish between Jews and Samaritans therefore it is more difficult to decide today whether a diaspora was Jewish or Samaritan. Even so, there are regions of the Eastern Mediterraneum where a Samaritan diaspora can be defined, though no history of any of them can be sketched.
\end{abstract}

Key words: Samaritans, Jews, diaspora, Hellenism, Gerizim, Egypt, Rhodos, Delos, Athen, Thessalonica, Asia Minor, Sicily

\section{INTRODUCTION}

The diaspora situation has been a well-known phenomenon of geographically determined large ethnic groups since ancient times. Remarkably enough Samaritans, as a small religious/ethnic group of Hellenistic-Roman Israel - sometimes defined as the first Jewish sect -, also had diaspora, though not as well documented as contemporaneous Jewish diaspora. The general unfamiliarity of this diaspora situation is primarily due to the problematic differentiation between Samaritans and Jews in antiquity. The similarity of the two groups made it impossible already for the rabbis of the Mishnah to make a clear distinction and certain decisions. ${ }^{1}$ If the religious experts of the Jews could not describe their distinctiveness with entire certainty, how could it be expected of non-Jews. Consequently, non-Jewish sources are more questionable in

\footnotetext{
${ }^{1}$ See the most recent studies on the rabbinic approaches to the Samaritans: LAVEE, M.: The Samaritan May Be Included - Another Look at the Samaritan in Talmudic Literature. In MOR, M. - REITERER, F. V. (eds.): Samaritans: Past and Present. Current Studies [SJ 53, StSam 5]. Berlin 2010, 147173. Friedheim, E.: Some Notes about the Samaritans and the Rabbinic Class at the Crossroads. In MOR-REITERER 193-202.
} 
making a distinction between Jews and Samaritans. Modern scholars started to encounter Samaritan Diasporas since the rediscovery of the Samaritans in the 17th century. When the very first Samaritan Pentateuch arrived to Europe by the Roman nobleman, Pietro Della Valle, the existence of Samaritans was recognized outside Shechem (Nablus) in Cairo, Damascus and Gaza. ${ }^{2}$ Later the recognition of earlier Jewish and Christian itineraries, ${ }^{3}$ the discovery of ancient texts and modern archaeological findings revealed a much wider Samaritan diaspora mainly in ancient times. In this article we are going to deal with the different aspects and problems of the Samaritan Diaspora and try clarify the reasons of its formation.

\section{PROBLEMS OF DEFINING SAMARITAN DIASPORA}

"We do not know when, why and where the Samaritan Diaspora began" - Pieter van der Horst started his analysis on the Samaritan Diaspora with these words. ${ }^{4}$ To clarify his quite pessimistic statement we can refer to the fact that there are several methodological problems concerning the definition of a Samaritan Diaspora. First of all the definition of Samaritans should be mentioned. If we identify the later Samaritans to be the descendants of northern Israelites, then the topic of the Samaritan Diaspora should be broadened to the Israelite Diaspora. Furthermore, the definition of the scope of the later Samaritan homeland provides another broadening to some parts of Palestine. A third group of problems is raised by the primary sources. Not all contem-

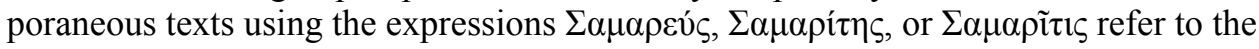
Samaritans, since the inhabitants of the region or city of Samaria could have been meant by these expressions. ${ }^{5}$ Not all texts dealing with Jews or Hebrews or Israelites refer only to Jews, sometimes Samaritans are also included. Concerning secondary sources we can detect the tendencies of the writers to highlight a contradiction between Jews and Samaritans, or to create a good and credible story, or simply the ignorance of the writer about his topics. The last problem is archaeology. An archaeological distinction between a Jewish and Samaritan synagogue can be made on two bases: orientation, and by the help of epigraphic evidences. Without any of these specifications archaeologists describe the synagogue to be Jewish. These problems define the approaches of discussing the Samaritan Diaspora.

\footnotetext{
${ }^{2}$ Pietro della Valle: Viaggi di Petro della Valle, il pelegrino. Bologna 1671, 406-408, 424.

${ }^{3}$ N. SCHUR (The Samaritans as Described in Christian Itineraries [14th-18th Centuries]. PEQ 118 [1986] 144-155) collected the earlier and later Christian itinerary records on Samaritans.

${ }^{4}$ VAN DER Horst, P. W.: Samaritans at Rome? In his Japhet in the Tents of Shem. Studies on Jewish Hellenism in Antiquity [BET 32]. Leuven 2002, 251-260, esp. 252. CROWN, A. D.: The Samaritan Diaspora to the End of the Byzantine Era. Australian Journal of Biblical Archaeology 2 (1974) 107-123.

${ }^{5}$ See also ZSENGELlÉR, J.: Kutim or Samarites. A History of the Designation of the Samaritans. In Shehadeh, H. - Tawa, H. - Pummer, R. (eds.): Proceedings of the Fifth International Congress of the Société d'Études Samaritaines. Paris 2005, 87-104. ILAN, T.: Lexicon of Jewish Names in Late Antiquity: Palestine 200-650 [TSAJ 148]. Leiden 2012, $27-28$.
} 


\section{ISRAELITE DIASPORA AS PRE-SAMARITAN DIASPORA}

If we identify Israelite Diaspora as pre-Samaritan Diaspora, two geographical directions have to be mentioned: Mesopotamia and Egypt.

The deportations of Tiglath Pileser III produced the first wave of Israelites getting into a diaspora situation. ${ }^{6}$ This was followed by the deportation by Sargon II. ${ }^{7}$ Accordingly Israelites were forced to live in the territory of the Assyrian orbit, but unlike in the case of the later Judean deportees we have no information whether they preserved their identity in the Exile. ${ }^{8}$ References to this type of preservation can be found in later Jewish literature, e.g. in the Book of Tobit, but they seem to be more literary compositions then reflections of reality. ${ }^{9}$

Deportations into Mesopotamia are also referred to in later Samaritan sources. The different Samaritan chronicles mention two deportations of the Samaritans: first by the Assyrians or the Babylonians, later by the Babylonians or the Greeks. ${ }^{10}$ But the returns of all the Samaritan deportees are also noted by these sources. ${ }^{11}$ Consequently, the Samaritan tradition does not hold the existence of a Samaritan Diaspora in Assyria and Babylon during or after the Persian period.

Some scholars refer to Gittin 45a of the Babylonian Talmud as a source of evidence for the Samaritan presence in the Babylonian Diaspora, ${ }^{12}$ though neither this text, nor other rabbinic texts contain any hints at the existence of Samaritans in Babylon. Since the sages who discussed the relationship between Jews and Samaritans were foremost Palestinian rabbis, or Babylonian ones who had visited Palestine, their stories mention the Jewish-Samaritan relationship in general or in Palestinian settings and no case refers to the Babylonian situation. ${ }^{13}$

${ }^{6}$ NA'AMAN, N.: Population Changes in Palestine Following Assyrian Deportations. TA 20 (1993) 104-124. ZADOK, R.: The Earliest Diaspora: Israelites and Judeans in Pre-Hellenistic Mesopotamia [Publications of the Diaspora Research Institute 151]. Tel Aviv 2002.

${ }^{7}$ Directions of Sargon's deportations were mentioned in 2Kgs 17. Cf. ODED, B.: Settlements of the Israelite and Judean Exiles in Mesopotamia in the 8th-6th Centuries. In GALIL, G. - WeINFELD, M. (eds.): Studies in Historical Geography and Biblical Historiography Presented to Zechariah Kallai [VTS 81]. Leiden 2000, 91-103.

${ }^{8}$ The single exception is Calah, from where there are some references to a "Samarian troop" in Sargon's army (CTN III 99, 113, 118), and to three Samarians receiving rations from the royal treasury (CTN III 121. 7-8). Cf. DALley, S.: Foreign Charioty and Calvary in the Armies of Tiglath Pileser III and Sargon II. Iraq 46 (1985) 31-48. ODED (n. 7) 93.

${ }^{9}$ MiLIK, J. T.: La patrie de Tobie. RB 73 (1966) 522-530, thought Tobit to be a Samaritan.

${ }^{10}$ Deportations: 1) Israel was occupied by the Assyrians and the people of the eight tribes, the Samaritans led by Aqbiah, the high priest, went into captivity at Haran in Chaldea (Ch II. §L E*-BB* p. 88; AS 214-215), or Nebuchadnezzar took the Samaritans with Aqbiah, the high priest, to Haran (T 401.14a; Sh 409. 50; AF 63. 5-64. 8 pp. 75-76; SY 45 p. 218); 2) In the time of the high priest Azaria the Samaritans were exiled by the Chaldeans (Sh 409. 55; AS 217) or by the Greeks (T 401. 14a-b; AF 66. 8 p. 79).

${ }^{11}$ Returns: 1) After 70 years of exile the Samaritans returned (Ch II. §M L*-N* p. 89; AS 215); the same return was told to have happened after Nebuchadnezzar (T 401; Sh 409. 52; AF 65. 11 p. 78); 2) 300000 Samaritans return from exile under Abdal (T401. 14b; Sh 408. 56; AF 66.12 - 68. 8 pp. 79-81; SY 45 pp. 219-220; AS 218).

${ }^{12}$ SCHUR, N.: History of the Samaritans [BEATAJ 18]. Frankfurt am Main 1992, 55.

${ }^{13} \mathrm{I}$ am indebted to Andreas Lehnard for discussing this problem with me. 
Another Israelite Diaspora could have been the Elephantine community in Egypt. Their origin can be connected to the conquest of the Assyrian king, Asshurahidina, who founded military posts from recruited or deported people from other occupied Assyrian provinces. ${ }^{14}$ According to the names containing Bethel on the papyri found in Elephantine, and the correspondence of the community with the Samarian administrative center, early scholarly opinion tried to connect these colonists to the Samaritans. ${ }^{15}$ Despite the obvious points of contact between the colonists and Israelites and Samarians, it is hard to demonstrate that there were Samaritans among the community of Elephantine. Or as Reinhard Pummer formulated: "The origin of Samaritanism is to be dated considerably later, and there is no reason why the colonists should be considered even proto-Samaritans rather than Jews."

The last but main argument against the identification of the Israelite Diaspora with the Samaritan Diaspora is the reservation concerning the definition of being Samaritan. In relation to Jews, being Samaritan means a Yahwist person honoring Mount Gerizim instead of Jerusalem. None of the cases mentioned before can be connected to this definition.

\section{PALESTINE AS A DIASPORA SITUATION FOR SAMARITANS}

Samaria, the Israelite district, Samerina, the Assyrian province, Samerin, the Persian province and Samaritis ${ }^{17}$ the Seleucid district gave the boundaries for the territory of the people who later came to be called Samaritans. The conquest of the city of Samaria by Alexander the Great resulted in the formation of a polis-like Greek settlement situation around the city in the western part of the previous province. ${ }^{18}$ The eastern part remained the region of the former mainly Yahwist population. ${ }^{19}$ Though this ter-

\footnotetext{
${ }^{14}$ Asshurahidina's deportations are noted by the text of Ezra 4:2. Cf. NA'AMAN (n. 6). There are different ideas about the formation of the Elephantine community. See ModRZEJEWSKI, J.: The Jews of Egypt: From Rameses II to Emperor Hadrian. Princeton 1997, 22-26.

${ }^{15}$ VAN GeldEREN, C.: Samaritaner und Juden in Elephantine-Syene. OLZ 15 (1912) 337-344. VAN HOONACKER, A.: Une communauté Judéo-araméene à Eléphantine au VI et $V^{e}$ siècles av. J.-C. London 1915. VERNES, M.: Éléphantiné et Béthel. JA 11 (1918) 370-376.

${ }^{16}$ Pummer, R.: The Samaritans in Egypt. In AMPHOux, CH-B. - SCHATTNER-RIESER, U. (eds.): Études sémitiques et samaritaines offertes à Jean Margain [Histoire du Texte Biblique 4]. Lausanne 1998, 213-232, esp. 214.

${ }^{17}$ Cf. 1Macc 10:30; 11:28.34. This name sometimes also involved Samaria, Galelee and Judea. A detailed discussion of the identity of this territory during the Ptolemaic and Seleucid era see in DUŠEK, J.: Aramaic and Hebrew Inscriptions from Mt. Gerizim and Samaria between Antiochus III and Antiochus IV Epiphanes [CHANE 54]. Leiden 2012, 65-74.

${ }^{18}$ DAR, S.: Landscape and Pattern. An Archaeological Survey of Samaria 800 B.C.E.-636 C.E. With a Historical Commentary by Shimon Appelbaum [BAR IS 308/1-2]. Oxford 1986, 12-16, 260.

${ }^{19}$ The ridden and persecuted inhabitants of western Samaria fled partly to the eastern part of Samaria, as revealed by the Wadi Daliyeh Papyri. See Cross, F. M.: Aspects of Samaritan and Jewish History in Late Persian and Hellenistic Times. HTR 59 (1966) 201-211. DUŠEK, J.: Les manuscrits araméens du Wadi Daliyeh et la Samarie vers 450-332 av. J.-C. [CHANE 30]. Leiden 2007. Archaeological researches have resulted in different outcomes about the density of the population and the prosperity of the region in this period. See FinKELSTEIN, I.: The Southern Samarian Hills Survey. NEAEHL 4 (1993)
} 
ritory was not determined as a separate entity in Samaritis, Ariyeh Kasher discussed the extent of the Samaritan territory called "enclave" by him. ${ }^{20}$ This term is rooted in the Talmudic designations: מטלית של /פסיקיה של כותים/רצועה מפסקת של כותים כותים (separate strip/girdle/enclave of the Cutheans). ${ }^{21}$

It was an inconstant territory around the temple city of Gerizim as its center, between Samaria and Bethel and between Lydda and the Jordan ${ }^{22}$ during the Hellenistic period. The territory suffered several military activities during this period, and hands from time to time, which could have resulted in the move of some inhabitants to other nearby or far away areas. This could be the case especially during and after the military campaign of John Hyrcanus in the last decade of the 2nd century BCE, who integrated this territory into the Hasmonaean Kingdom, and tried to assimilate its followers into the Jerusalem cult by the destruction of the Gerizim Temple. ${ }^{23}$

Later in the Roman period the extent of Samaritan settlements reaches as far as Antipatris in the South, Qalqiliya in the West, and Yenin in the North. The Rabbinic references and the archaeological identifications provide a list of the Samaritan cities. ${ }^{24}$ Following these data Yitzhak Magen presented a distribution map of the Samaritan settlements. ${ }^{25}$ Samaritans settled in Roman cities outside the Samaritan "enclave" like Sebaste, Scythopolis, Caesarea, Gaza, Ascalon, Yamnia, Ashdod and Antipatis. Later Samaritan Synagogues were found in Beth-Shean, Ramat Aviv and Sha'alvim, ${ }^{26}$ but Josephus and rabbinic sources also refer to a Samaritan presence in these cities. Samaritan migration to Roman cities as well as to previous Jewish settlements was facilitated by the fall of the Jewish War and of the Bar Kochba Revolt. ${ }^{27}$

The integration of Samaritans into the commercial, social, administrative and cultural life of cities in Roman Palestine sometimes led to a competition between them and the Jews living in the same cities. As Yitzhak Magen notes: "Jews were suddenly confronted with a Samaritan community different from that previously known; this contact compelled halakhic authorities to relate to the Samaritans dwelling in their midst, where previously each people had resided in its own territory." 28 Rabbinic discourses concerned with the problems of the Samaritans are pre-eminently connected to situa-

1313-1314, and ZeRTAL, A.: The Manasseh Hillcountry Survey. Vol. I-II [CHANE 21.1-2]. Leiden 2008.

${ }^{20}$ KASHER, A.: Jews and Hellenistic Cities in Eretz-Israel. Tübingen 1990. KASHER, A.: The Enclave of Cutheans - A Factor in Jewish-Samaritan Relations in Antiquity. In SHEHADEH-TAWA-PUMMER (n. 5) 205-221.

${ }_{21}^{21}$ jHag iii, 79c; jDem v, 25c; bHag 25a; Eikhah Rabbah iii, 7. Cf. KASHER: The Enclave (n. 20) 206.

${ }^{22}$ Cf. the maps in ZSENGELLÉR, J.: Gerizim as Israel. Northern Tradition of the Old Testament and the Early History of the Samaritans [Utrechtse Theologische Reeks 38]. Utrecht 1998, 195-196.

${ }^{23}$ Ant 13. 255-256, 275-281.

${ }^{24}$ There are also New Testament references to the settlements of Samaritans, e.g. Matt 10:5-6: "These twelve Jesus sent out with the following instructions: 'Do not go among the Gentiles or enter any town of the Samaritans. Go rather to the lost sheep of Israel." (NIV)

${ }^{25}$ MAGEN, Y.: The Samaritans and the Good Samaritan [JSP 7]. Jerusalem 2008, 80.

${ }^{26}$ MAGEN (n. 25) 117.

${ }^{27}$ One example is jKid 4:65d: "R. Abbahu said: Thirteen towns were settled by Cutheans during the time of anti-Jewish persecutions."

${ }^{28}$ MAGEN (n. 25) 83. 
tions and locations where they lived together. These circumstances have resulted in both positive and negative views. ${ }^{29}$

In sum, Palestine, outside the Samaritan "enclave", provided the primary destination of Samaritan migration. In most cases, these were former Israelite-Judean territories, but they did not belong to the area of the Gerizim community, and were populated by Jews and other non-yahwist ethnicities. Therefore the situation can be described as a Diaspora.

\section{SAMARITAN DIASPORAS OUTSIDE OF PALESTINE}

The first reports on Samaritan settlements outside Palestine were told by Josephus Flavius. According to him, after the siege of Tyre and Gaza where Samaritan troops were told to support Alexander's army, Alexander took some of these troops to Egypt and settled them in the Thebaid to guard the district.

Now Sanaballetes ... came, along with eight thousand of the people under his rule, to Alexander, whom he found beginning the siege of Tyre... (Ant. 11.321)

the soldiers of Sanaballetes he [Alexander] ordered to accompany him to Egypt; there he said, he would give them allotments of land, as in fact he did shortly afterwards, in the Thebaid, and this territory he ordered them to guard. (Ant. 11.345)

This information forms the frame of three meetings of Alexander in Palestine (Sanballat, Jewish High Priest, Samaritans), though none of them seems to have been a historical event. But except Sanballat, who lived rather in the 5th century, ${ }^{30}$ there can be some real data in these sentences and some people of Palestine or especially of the region of Samaria would have been involved in Alexander's campaigns against Tyre and Gaza. Even the settling of soldiers from this region in Egypt is acceptable, but no military post like Elephantine was created only of these soldiers. ${ }^{31}$

According to Arrian, the Roman historian, after the siege of Gaza the city needed to be repopulated, therefore

\footnotetext{
${ }^{29}$ The Samaritan Diaspora inside Palestine was discussed in details by BEN ZWI, Y.: Sepher HaShomronim. Jerusalem $1970^{2}, 76-133$.

${ }^{30} \mathrm{Cf}$. Against the previous verification of a Sanballat in Alexander's time by Cross, DUŠEK: Les manuscrits (n. 19) 458. pointed out that there was only one Sanballat referred to in Neh 13; Elephantine Papyri, and the Wadi Daliyeh Papyri and bulla.

${ }^{31}$ The main problem of this account is not the large number of the soldiers - as PUMMER (n. 16) 214 proposed, since only the remnants of the eight hundred after the two sieges are meant here - but the name Thebaid. Thebaid, the district south of Hermopolis, has provided no reference to any Samaritan presence so far. But according to O. MONTEVECCHI (Samaria e Samaritani in Egitto. Aegyptus 76 [1996] 81-92, esp. 89) in the older division of Egypt Thebaid had the meaning of the entire Nile valley including the Fayyum from where we have some relating sources.
} 
having peopled the city again from the neighbouring settlers, he [Alexander] made use of it as a fortified post for the war. ${ }^{32}$

Crown presumed Samaritans of Sanballat's army among these "neighbouring settlers," 33 but this is neither stated by Josephus nor referred to by Arrian. The later existence of a Samaritan community in Gaza is known from Samaritan inscriptions and from the Ottoman tax registers (tahrirs). ${ }^{34}$

Though the reference to Samaritans or the historicity of these accounts could be questioned, it seems to be reasonable that since the dawn of Hellenistic presence in the region, forced and open migrations provided the possibility of the beginning of the Samaritan Diaspora outside Palestine and especially in the East Mediterraneum. ${ }^{35}$

\section{EGYPT}

Ancient Jewish authors referred to the settling of Samaritans in Egypt. The author of the Letter of Aristeas mentions his idea of "the emancipation of the Jews who had been transported from Judaea by the king's father". He describes this transportation of Ptolemy I:

he had brought his attack on the whole district of Coele-Syria and Phoenicia to a successful issue, in the process of terrorizing the country into subjection, he transported some of his foes and others he reduced to captivity. The number of those whom he transported from the country of the Jews to Egypt amounted to no less than a hundred thousand. Of these he armed thirty thousand picked men and settled them in garrisons in the country districts. ... but the great mass of the others, those who were too old or too young for this purpose, and the women too, he reduced to slavery. (Let. Arist. 12-14)

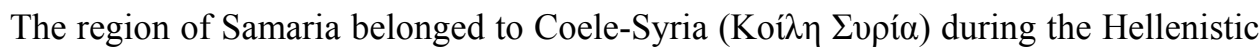
period, thus among the deportees from Coele-Syria and Phoenicia there could have been people living in and migrated from the region of Samaria, or especially those who belonged to the Gerizim community.

In a double report Josephus writes about quarrels between the descendants of the Samaritans and the Jews who had been settled in Egypt. The first quarrel was written to have occurred under Ptolemy I Soter (304-282 BCE, Ant. 12. 7-10), the second under Ptolemy VI Philometer (180-145 BCE, Ant. 13. 74-79).

\footnotetext{
${ }^{32}$ Arrian, Anabasis of Alexander II 27. 7.

${ }^{33}$ CROWN (n. 4) 109-110.

${ }^{34}$ Cf. BEN ZWI (n. 29) 116-117.

${ }^{35}$ Pummer (n. 16) 214.
} 
In the first report we read about the ruler, that he

took many captives both form the hill country of Judaea and the district round Jerusalem and from Samaria and those on Gerizim and brought them all to Egypt and settled them there. (Ant. 12.7)

In determining the origin of some of the captives as Samaria and especially as Gerizim, Josephus specified the above description of the author of the Letter of Aristeas. ${ }^{36}$ Next to the deportations Josephus also referred to free migrations of Jews and others from Syria into Egypt in Ant. 12. 9; Ag. Ap. 1. 186. 194. ${ }^{37}$ The time of these forced and free migrations could be connected to the campaigns of Ptolemy I in 312 or 302/301 BCE. ${ }^{38}$ Consequently, according to the ancient Jewish authors a significant migration of the Samarian population took place at the end of the 4th century BCE, when Palestine became subject to Ptolemaic Rule.

Josephus writes in both cases of the above mentioned double report that the dispute between Jews and Samaritans in the Diaspora concerned the legitimacy of the temples in Jerusalem and on Mt. Gerizim. In these cases this topic specifies the parties to be Jews and Samaritans. The second report put the scene of the quarrel into Alexandria, which does not seem to be correct, since there is no further information about Samaritans living in this city in the Hellenistic period. Several legendary elements also colored these stories, but probably there is a historical core to the accounts about dispute(s) between Samaritans and Jews somewhere in Egypt at least in the 2nd century BCE which could be the earliest literary evidence for a Samaritan Diaspora in Egypt in the 3rd-2nd century BCE. This conclusion can be supported by the appearances of Samaritans on Egyptian papyri since the middle of the 3rd century BCE.

A village called $\Sigma \alpha \mu \alpha \dot{\alpha} \rho \varepsilon \_\alpha$ is mentioned in several papyri found in the Fayyum (Arsinoites). ${ }^{39}$ Though its precise place is unknown, ${ }^{40}$ references located this village near to ancient Kerkesephis and Tebetny in the period between $254 \mathrm{BCE}$ and 289 $\mathrm{CE}^{41}$ It is quite obvious that at least since the middle of the 3rd century BCE the village was named after the city or region of Samaria in Palestine. Interestingly no

\footnotetext{
${ }^{36}$ Some scholars believe that Josephus paraphrased the Letter of Aristeas here. Cf. R. PUMMER: The Samaritans in Flavius Josephus [TSAJ 129]. Tübingen 2009, 182.

${ }^{37}$ Concerning these references in his Against Apion, Josephus writes to cite and paraphrase the work of the Greek historian Hecateus. Cf. BAR-KochVA, B.: Pseudo-Hecateus On the Jews: Legitimizing the Jewish Diaspora. Berkeley-London 1996, 71-74.

${ }^{38}$ See BAR-KochVA (n. 38) 76-77; PUMMER (n. 36) 182, n. 5-6.

${ }^{39}$ There are 41 papyri mentioning Samareia: 3 from Magdola, 1 from Ptolemais Euergetis, 3 from Polemonos Meris, 12 from Tebtynis, 11 from Arsinoites, 11 unknown but from the Fayyum. See KuHs, C.: Das Dorf Samareia im griechisch-römischen Ägypten. Eine papyrologische Untersuchung (unpublished MA thesis from the Universität Heidelberg 1996 = http://archiv.ub.uni-heidelberg.de/volltextserver/479/1/ samareia.pdf), 25.

${ }_{40}$ "Zum einen ist Samareia niemals ausgegraben worden, zum anderen auch nicht mit einem heutigen Ort identifiziert worden." KuHS (n. 39) 31.

${ }^{41}$ Flinders Petrie Papyri II 4. 11 dated to 7th August 254 BCE; MAHAFfy, J. P. - GilBart, S. J.: The Flinders Petrie Papyri with Transcriptions, Commentaries and Index [Cunningham Memoirs 9 and 11]. Dublin 1893 and 1905. BGU I 94 dated to 4th December 289 CE: HAGEDORN, H. (et al.): Griechische Urkundenpapyri der Bayerischen Staatsbibliothek München. Teil 1. Stuttgart 1986.
} 
less than 19 of the 85 persons mentioned by name from Samareia in the papyri of the

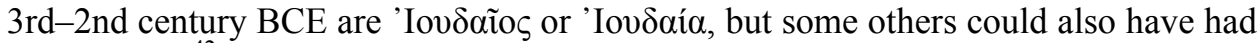
this identity. ${ }^{42}$ Contrarily no Samarian or Samaritan is mentioned in Samareia. It is, however, questionable whether a Judean majority would have called their village by this name. Some scholars assume that the Samari(t)ans "gradually must have intermarried with Jews and the settlement lost its original character". ${ }^{43}$ On the other

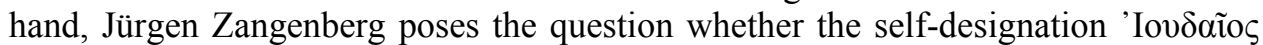
in certain papyri from this Samareia would refer to assimilated Samaritans or Samaritans who converted to Judaism. ${ }^{44}$ Another opinion was raised by Montevecchi, namely that Jews and Samaritans were not distinguishable for the local administration, there-

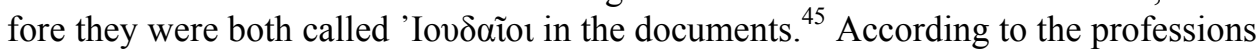
of the persons and their date of life mentioned in the papyri we can somewhat modify Tcherikover's earlier statement and assume that this Samareia was at first probably a military settlement of soldiers from Syria, particularly Samari(t)ans and Jews. ${ }^{46}$ Later, as Piet van der Horst also noted, "in Egypt the term $\Sigma \alpha \mu \alpha \rho \varepsilon i ́ \tau \alpha$ received the additional meaning of "inhabitant of the village of Samareia"," 47

Further data on Samari(t)an presence in ancient Egypt is provided by personal names having the attribute Samari(t)an. There are three names in different papyri with some variant of $\Sigma \alpha \mu \alpha \rho \varepsilon v ́ c$. A certain $\Sigma \alpha \mu \alpha \rho \rho \varepsilon$ from Philadelphia (Herakleidu Meris), and A BCE. $^{48}$ A person bearing the name $\Sigma \alpha \mu \alpha \rho i ́ \omega v$ in the papyrus from Theadelphia lived in the 2nd century CE. ${ }^{49}$ All of these persons could have had some connections either to Samaria in Palestine or Samareia in Egypt. There are four names in different pa-

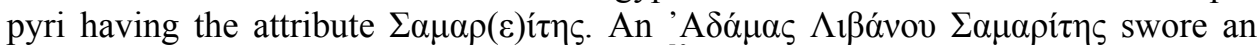
oath on 27th February $221 \mathrm{BCE}$ in Magdola. ${ }^{50}$ A 'I $\alpha \sigma \omega v \Sigma \alpha \mu \alpha \rho \varepsilon i$ i $\rceil$ s is mentioned in

${ }^{42} 85$ names have been preserved from this period, and 19 are called Jews. (CPJ I 22. 133; CPR XVIII 7-11). See KUHS [n. 39] 77-79. But according to the form and content of their names he presumes further 28 Jewish identities (79-81) and also 18 "perhaps Jews" (81-83) among these names.

${ }^{43}$ Summary of Pummer (n. 16) 4. See KASHER, A.: The Jews in Hellenistic and Roman Egypt. Tübingen 1985, 148; HeNGEL, M.: Judaism and Hellenism. Vol. II. London 1974, 11, n. 87.

${ }^{44}$ ZANGENBERG, J.: SAMAREIA: Antike Quellen zur Geschichte und Kultur der Samaritaner in deutscher Übersetzung [TANZ 15]. Tübingen-Basel 1994, 303. He gave an indirect negative answer to this question.

${ }^{45}$ Montevecchi (n. 31) 91. 5, n. 12.

${ }^{46}$ Cf. TCHeriKover, V. A. - FUKS, A.: Corpus Papyrorum Judaicarum Vol. I. Cambridge 1957,

${ }^{47}$ VAn DER Horst, P. W.: The Samaritan Diaspora in Antiquity. In his Essays on the Jewish World of Early Christianity [NTOA 14]. Freiburg-Göttingen 1990, 136-147, esp. 139.

${ }_{48}$ P.Cair.Zen IV 59697 r. line 4 is dated to 263-256 BCE. For text, data and image, see http:// papyri.info/ddbdp/p.cair.zen;4;59697 . P.Petrie ${ }^{2}$ I, 1. r. line 76 is dated to 238-237 BCE. For text, data and image, see http://papyri.info/ddbdp/p.petr.2;1.

${ }^{49}$ P.Berl.Leihg II 39 v. col 8. line 209. For text, data and image, see http://papyri.info/ddbdp/

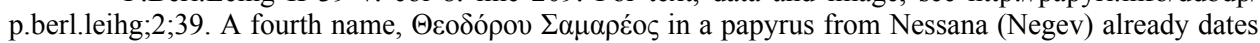
from the 6th-7th century CE. (P.Ness III $91 \mathrm{col} 1$. line 5. For text and data, see http://papyri.info/ddbdp/ p.ness;3;91).

${ }^{50}$ P. Enteux 62 line 1. Text and data, see http://papyri.info/ddbdp/p.enteux;;62. 
an administrative list from Tebtynis dated to $\left.109 \mathrm{CE} .{ }^{51}{ }^{\circ} \mathrm{H} \rho \omega \nu \Sigma \alpha \mu \beta \tilde{\alpha} \Sigma \alpha \mu \alpha \rho i ́ \tau\right\rceil \varsigma$ was

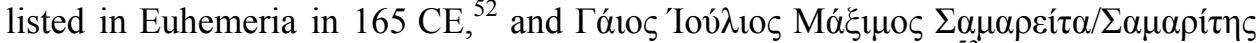
four times in two tax rolls from Karanis between 171-174 CE. ${ }^{53}$ As Nagel pointed out, names of villages with the ending $1 \tau\rceil \zeta / \varepsilon ı \tau\rceil \zeta$ were frequent from the second half of the 2nd century CE, first as cognomens, later as official designations of a person's origin. ${ }^{54}$ The two latter cases belong surely to this category, but there is no data for a different explanation in the first two cases either. Consequently, these persons were also either from Samaria in Palestine or from the village Samareia as the previous ones, and there is no direct evidence of their Samaritan identity,${ }^{55}$ although the word $\Sigma \alpha \mu \alpha$ ítns in Jewish literary sources designated Samaritans, the people of the Gerizim community since the 1 st century $\mathrm{CE}^{56}$

In contrast, the presence of Samaritans in Alexandria seems to be evident by references of church fathers like Origen. In his works De principiis written in Alexandria between 220 and 230 CE Origen mentions a certain Dositheus, the Samaritan

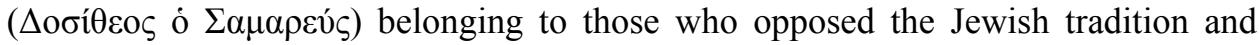
"believe that in whatever position a man is found on the Sabbath day he should remain there until evening" (4. 3. 2, 17). A $\Sigma \alpha \mu \alpha \rho \varepsilon v ́ \varsigma$ as an opponent of the Jewish Sabbath observance could have been a Samaritan. All the more so, since the existence of a Samaritan sect called Dositheans ${ }^{57}$ in Egypt was also stated by Eulogius, Patriarch of Alexandria, still in the 6th century CE (580-607). ${ }^{58}$

A 4th-century rewriting of the life of the Caesars, the Historia Augusta mentions Samaritans in Egypt along with Jews and Christians. According to the negative description of the inhabitants of Egypt in a letter of the emperor, they are labelled to be astrologists, diviners and charlatans. Some of their professions are also listed: "blowers of glass, makers of paper, weavers of linen". ${ }^{59}$ The writer of this fictitious letter of Hadrian describes the Samaritans for the first time as one of the religious groups of Egypt.

Further evidence comes from the first Roman law that mentions Samaritans along with Jews. On February 18th, 390, emperor Theodosius issued a decree stating:

${ }^{51}$ P. Mil. Vogl IV 212. r. col. I. line 1, and col. X. line 2. For text and data, see http://papyri.info/ ddbdp/p.mil.vogl;4;212.

${ }_{52}$ P. Straß. IX 866 v. line 21. For text and data, see http://papyri.info/ddbdp/p.stras;9;866.

${ }^{53}$ P. Mich IV 223 lines 1483. 1679; and 224 lines 1400. 3342. For texts and data, see http:// papyri.info/ddbdp/p.mich;4.1;223 and http://papyri.info/ddbdp/p.mich;4.1;224.

${ }^{54}$ See NAGEL, M.: Un Samaritain dans l'Arsinoïte au IIe siècle après J.-C. (à propos du nom Sambas). Chronique d'ÉEypte 49 (1974) 356-365.

${ }_{55}$ For a detailed analysis of all these names, see KUHS (n. 39) 26-30. He also listed three more names from the 6th-7th century CE having the cognomen $\Sigma \alpha \mu \alpha \rho i \tau(\eta \varsigma)$ : P.Herm 40; P.Ness III 95 line 17 (CPJ III 513); P.Sorb II 69.

${ }^{56}$ See ZSENGELLÉR: Kutim (n. 5).

${ }^{57}$ On this sect see ISSER, S. J.: The Dositheans. A Samaritan Sect in Late Antiquity [SJLA 17]. Leiden 1976.

${ }^{58}$ Photius, Bibliotheca 230, 285a.24 - 286b.42; see PUMMER, R.: Early Christian Authors on Samaritans and Samaritanism [TSAJ 92]. Tübingen 2002, 425-429.

${ }^{59}$ Vita Saturnini 7. 5 and 8. 3. See STERN, M.: Greek and Latin Authors on Jews and Judaism. Vol. II. Jerusalem 1980, 636-641. 
It has been established that the community of the Jews and the Samaritan community (Iudaeorum corpus ac Samaritanum) are illegally nominated to the duty of maritime transport; for what is seen to be imposed on the whole community cannot bind a person specifically. ${ }^{60}$

This law offers the first evidence that the Samaritan community in Egypt or especially in Alexandria was recognized as a corpus by the authorities. It also provides data that Samaritans worked as ship-owners and sailors in Egypt.

There are two real Samaritan documents from the 5th-6th century CE from Egypt. The first is a letter, the unknown author of which swears by Mount Gerizim:

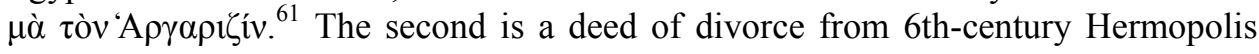
(CPJ III 513). The parties of the document, Aurelios Iustos son of Sampsikos and

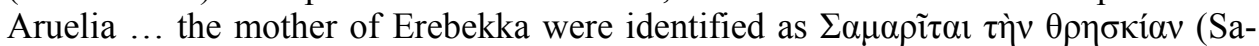
maritans by faith), and the date of its issue was July 26th, $586 \mathrm{CE} .^{62}$ Both documents are connected to the religion of the persons who were surely Samaritans.

It is hard to define the beginning of the Egyptian diaspora of the Samaritans in the Hellenistic period, but also later on there are only sporadic sources. Samaritans seem to have started to live in the Fayyum and existed in Alexandria, later concentrated only to Cairo, where their community ceased approximately around $1700 \mathrm{CE} .^{63}$

\section{THE COASTAL PLAIN AND ASIA MINOR}

In Tyre a tomb inscription is found with the text $\Sigma \alpha \mu \alpha \rho \varepsilon i$ ív $\dot{\varepsilon} \lambda \varepsilon v$ $\theta \varepsilon \rho o v$, "a Samari(t)an freeman". 64 Though the Samaritan provenance of this man is not provable, the story of Josephus on the Samaritan supply of Alexander's military campaign against Tyre can support the idea of Samaritans living in Tyre. ${ }^{65}$

${ }^{60}$ Cod. Theod. 13. 5. 18. Text: MommSEn, TH. - MEYER, P. (eds.): Theodosiani libri xvi cum constitutionibus sirmondianis. Berlin 1905, 752; translation with notes and short discussion: LINDER, A.: The Jews in Roman Imperial Legislation. Detroit 1987, 182-185.

${ }^{61}$ P.Heid IV 333 r. line 14. Text: http://papyri.info/ddbdp/p.heid;4;333. Image: http://www.rzuser. uni-heidelberg.de/ gv0/Papyri/P.Heid._IV/333/P.Heid._IV_333_Rekto_\%28150\%29.html. See HAGEDORN, D.: Byzantinischer Brief aus samaritanischem Milieu $(P . \bar{H} e i d . I \bar{V})$. Heidelberg 1986, 225.

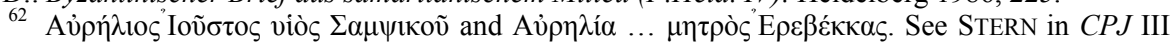
103-104. Cf. also PUMmer, R.: Samaritan Marriage Contracts and Deeds of Divorce. Vol. I. Wiesbaden 1998, 238-239.

${ }^{63}$ There are literary references to Levitical priests who copied sacred scrolls and of a Samaritan synagogue in Cairo. For further details on Samaritans in Egypt in mediaeval and modern times, see Crown, A. D.: The Samaritan Diaspora. In his The Samaritans. Tübingen 1989, 195-217, esp. 213-215. and PuMMER (n. 62) $215 \mathrm{ff}$.

${ }^{64}$ See ReY-COQUAIS, J.-P.: Inscriptions grecques et latines découvertes dans les fouilles de Tyr (1963-1974) I: Inscriptions de la nécropole [Bulletin du Musée de Beyrouth 39]. Paris 1977, no. 168.

${ }^{65}$ Ant. 11. 321. In the Samaritan chronicle Kitab al-Tarik of Abu 1-Fath, Samaritans were mentioned living around Tyre in the time of Alexander. STENHOUSE, P.: The Kitāb al-Tarikh of Abu 'l-Fath. Translated into English with Notes [Mandelbaum Studies in Judaica 1]. Sydney 1985, 113. The same story is mentioned in the later Samaritan Book of Joshua: JUYNBOLL, T. G. J. (ed.): Chronicon Samaritanum. Leiden 1848, 116. 
The other city of this area which really had a Samaritan population was Constantinople. There are no direct data from antiquity, but the information preserved from the 5th and 6th centuries demonstrates that Samaritans had been living in the city for centuries. The collection called Theodosian Code has a chapter with the heading De Iudaeis, Caelicolis et Samaritanis. Though Jews and Samartians were called differently, the language of the laws before the time of emperor Justinian shows that they were treated together as one ethnic group. ${ }^{66}$ The legislation was intended for the whole empire; consequently, Samaritans were known elements of the Byzantine orbit. A Law of Theodosius II, January 31, 439 - Novella III: Concerning Jews, Samaritans, Heretics, and Pagans forbids these non-Christians to obtain offices and dignities:

none shall the administration of city service be permitted; nor shall any one exercise the office of a defender of the city. Moreover, for the same reason, we forbid that any synagogue shall rise as a new building. However, the propping up of old synagogues which are now threatened with imminent ruin is permitted. ${ }^{67}$

The Justinianic Code further restricted the position of the Samaritans. They were forbidden

to obtain any position of dignity, acquire any girdle of office, civil or military, or to belong to any order whatever except to that of the so-called provincial apparitors (cohortalium). (Cod. Iust. I 5. 12. 6) ${ }^{68}$

If any heretics, and above all pagans, Jews, or Samaritans, and those who are like them, hold any of the aforementioned places, and having acquired any position of rank, ... we order them to be immediately removed therefrom. (Cod. Iust. I 5. 12.9)

The above cases treated Samaritans together with Jews and others, but a special treatment formulated exclusively against the Samaritans was recorded as well:

The synagogues of the Samaritans shall be destroyed, and if they attempt to erect others, they shall be punished. They can have no successors either by will or intestacy, except orthodox persons. They shall make no gift or transfer any property to anyone not orthodox; but the bishops and presidents shall see to it that the fisc will get it. (Cod. Iust. I 5. 17)

By the realization of this law Samaritans could have lost the possibility of practicing their faith as a community. Living in a Diaspora situation it should have meant an end to organized religious life. But as individuals, Samaritans were also forbidden to leave heritage to others than orthodox Christians, to disinherit their children con-

${ }^{66}$ Cf. LINDER (n. 60) 61-62. The Third Novel of Theodosius reads as follows: "No Jew - or no Samaritan who subscribes to neither [the Jewish nor the Christian] religion." See the reference in the next note. No. 429 .

${ }^{67}$ Coleman-Norton, P. R.: Roman State and Christian Church. 3 vols. London 1966, 711-715,

${ }^{68}$ Cod. Iust. I 5. 12. See in COLEMAN-NORTON (n. 67) 995-999; No. 567.

Acta Ant. Hung. 56, 2016 
verted to Christianity, to act as witnesses in lawsuits, and to hold Christian slaves. ${ }^{69}$ Since these laws were put in force by $527 \mathrm{CE}$ "not only in this glorious city, but in all provinces, and throughout the world", ${ }^{70}$ the Samaritan Diaspora was in decline further on.

In his Anecdota (Historia Arcana) Procopius, the historian of Justinian, writes the following about a Samaritan in the time of emperor Justinian:

There was a certain Faustinus, born in Palestine, a Samaritan by descent, but under the constraint of the law he had espoused the name of Christian. This Faustinus had risen to the senatorial rank and was ruler of the land; but a little later he was removed from this office and came to Byzantium, where some of the priests began to slander him, alleging that he was observing the rites of the Samaritans and basely mistreating the Christians living in Palestine. ${ }^{71}$

Faustinus was punished to pay a penalty to the emperor and then he was appointed "Overseer of the Imperial Domains in Palestine and Phoenicia". If this story of Procopius is true, then there were Samaritans who converted only virtually to Christianity but lived secretly further on as Samaritans. ${ }^{72}$

\section{THE DIASPORA IN GREECE}

Two inscriptions from Rhodos have unidentified Samaritan readings. The name 'Po-

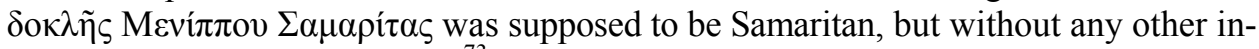
dication his identity is dubious. ${ }^{73}$

The best and real Samaritan inscriptions have been found in Delos. ${ }^{74}$ The two dedicatory texts do not mention the words Samaria or Samari(t)ans, but their contents confirm that the dedicators were Samaritans.

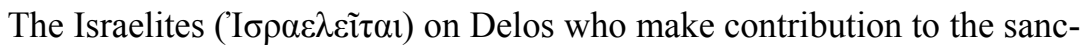

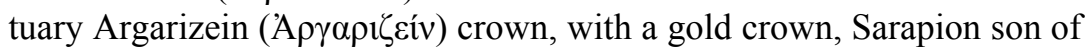
Jason, of Knossos, for his benefactions toward them. (Inscr. no. 1)

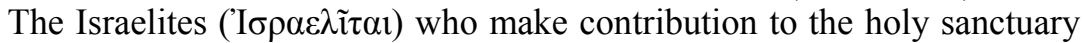
Argarizein honor Menippos, son of Artemidoros, of Herakleion, both 324-327)

${ }^{69}$ Cod. Iust. I 5. 18, 19, 21; I 10. 2. COLEMAN-NORTON (n. 67) No. 575, 599, 622, 647.

${ }^{70}$ Cod. Iust. I 5. 12. 10. COLEMAN-NORTON (n. 67) 995-999; No. 567.

${ }^{71}$ Procopius, Anecdota 27. 26-31 (transl. H. B. DEWING, in Loeb Classical Library vol. VI, 1935,

${ }^{72} \mathrm{He}$ had a somewhat similar story about a certain Arsenius, a wealthy Samaritan. Cf. Procopius, Anecdota 27. 6-20.

${ }^{73} I G$ XII 1. 716; IG XII 8. 439. See Robert, J. - ROBERT, L.: Bulletin épigraphique no. 369. REG 82 (1969) 477-478.

${ }^{74}$ The text was first published by P. BRUNEAU: Les Israélites de Délos et la Juiverie Délienne. BCH 106 (1982) 465-504. 
himself and his descendants, for constructing and dedicating, out of his own funds ... (Inscr. no. 2$)^{75}$

The dedicators were Samaritans, identified themselves as Israelites in Delos, who distinguished themselves from other Israelites, namely from those who send their contribution to Jerusalem (to Mount Zion). A Jewish synagogue was identified next to the building where the inscriptions were found.$^{76}$ Was this not a Samaritan synagogue? The inscriptions could be interpreted as giving honor to the benefactions for the building of a synagogue. ${ }^{77}$ The date of these inscriptions is between the $3 \mathrm{rd}$ and 1 st century BCE. ${ }^{78}$ If a contribution or temple tax should have been paid for a temple, it stands to reason that the inscriptions predated the destruction of the temple on Mount Gerizim by John Hyrcanos in 109/108 BCE. Consequently, a remarkable Samaritan community existed on the island of Delos next to the Jewish community.

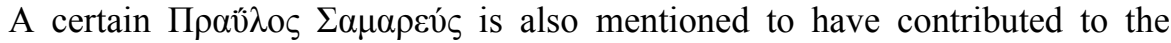
building of a Serapis temple in Delos at the end of the 1st century BCE. According to his action he was not a religious Samaritan, rather a Hellenistic Samarian. ${ }^{79}$ At this point a further distinction should be made. With the post-Alexandrian inscriptions the Samarians mentioned are not the same Samarians referred to before. Prior to the Hellenization of Samaria the inhabitants were mostly Yahwists by faith. Afterwards they were non-Yahwists or better to say Hellenists.

Three epitaphs form Athens mention persons with the adjective "Samaritan",

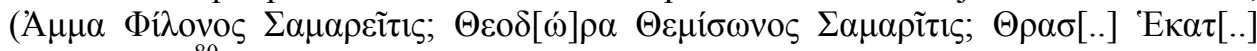
$\Sigma \alpha \mu \alpha \rho[\imath \tau .].),{ }^{80}$ but from the port of Athens, Pireus, the possibility of the Samaritan

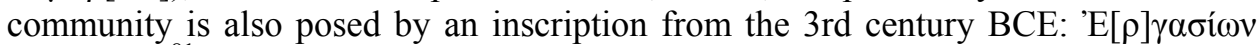
$\Sigma \alpha \mu \alpha \rho \imath \tau \varsigma^{81}$ In Poethius Bibliotheca the Vita Isidori of Damascius of Damascus mentions a certain Samaritan Marinus from Neapolis as the head of the Platonic Academy:

(141) He says that the successor of Proclus, Marinus, came from Neapolis in Palestine, a city situated near the mountain called Argarizon. Then the impious writer uttered the blasphemy that on this mountain there is a most holy sanctuary of Zeus the Highest, to whom Abraham the father of the old Hebrews consecrated himself, as Marinus himself maintains.

\footnotetext{
${ }^{75} \mathrm{I}$ accept the explanation and follow the translation of DUŠEK (n. 17) 75-79.

${ }^{76}$ BRUNEAU (n. 74) 485 supposed that there was only one synagogue that was Jewish. The opposite view was assumed by PUMMER, R.: Samaritan Material Remains and Archaeology. In CROwn, A. D. (ed.): The Samaritans. Tübingen 1989, 135-177, esp. 150-151. and DEXINGER, F.: Der Ursprung der Samaritaner im Spiegel der frühen Quellen. In DEXINGER, F. - PUMMER, R. (eds.): Die Samaritaner [Wege der Forschung 604]. Darmstadt 1991, 67-140, esp. 118.

${ }_{78}^{77}$ See VAN DEN HORST (n. 47) 144.

${ }^{78}$ Inscr. no. 1 was dated to ca. $150-50$ BCE and Inscr. no. 2 to ca. 250-175 BCE. See the recent discussions in KARTVEIT, M.: Origin of the Samaritans [VTS 128]. Leiden-Boston 2009, 218-219; DUŠEK (n. 17) 76.

${ }^{79}$ BRUNEAU (n. 74) 479.

${ }^{80} I G$ II $^{2} 10219-10221$. See ROBERT-ROBERT (n. 73) 478.

${ }^{81} I G \mathrm{II}^{2} 2943$ IV. See ROBERT- ROBERT (n. 73) 478.
} 
Marinus, though originally a Samaritan, gave up their creed, since it deviated from Abraham's religion and introduced innovations in it, and fell in love with paganism. (142) Nevertheless, by working hard, and untiring toil, Marinus surpassed in renown the fame of many abler and elder men. (143) Isidorus did not let Marinus be questioned as he had already been troubled by weakness, and he took care not to annoy him. (144) However, it is clear that Marinus, to judge from what he said and what he wrote, which did not amount to much, was not a profound originator of the fruitful ideas that give rise to wise opinions about the nature of things. (GLAJJ II 673-674) $)^{82}$

The text defines Marinus as a Samaritan in origin ${ }^{83}$ we do not know anything about the other persons in the above inscriptions. Therefore it is not enough to describe a Samaritan community in Athens.

Much more sure is the existence of a Samaritan community in Thessalonica. The remnants of their synagogue are identified by a ca. 5th-6th-century inscription. ${ }^{84}$ The inscription was carved on a white marble plaque containing a text with two lines in Samaritan Hebrew script: ברוך שמו לעולם, ברוך אלהינו לעולם. Between these blessings and the text of Num 6:22-24 a dedicatory text can be read in Greek. ${ }^{85}$ The dedication reads as follows: "God is one. Blessing to Siricius who has made with his wife and children. Neapolis may prosper with all its friends." ${ }^{86}$ The inscription was found nearby a church which was erected from an earlier non-Christian sanctuary. A tower on the old city wall is traditionally called "Samaritan Tower", which indicates a longer presence of Samaritans in the city. This is the only surely Samaritan synagogue outside Palestine, even so we do not know much about the Samaritans in Thessalonica.

\section{ITALY}

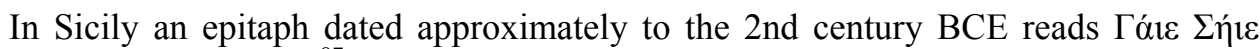
$\Pi \tau \sigma \lambda \varepsilon \mu \alpha \tilde{\varepsilon} \varepsilon \Sigma \alpha \mu \alpha \rho \varepsilon \tilde{v}^{87}$ Again an unidentified person, but in Syracusa of Sicily an

\footnotetext{
${ }^{82}$ STERN (n. 59) II 674. Stern remarks: "The emergence of a Samaritan philosopher in the second half of the 5th century CE accords well with the general impression given by the sources of the strength of the Samaritan element both in Palestine and outside it in the Byzantine period." (675).

${ }^{83}$ There are some queries about the Samaritan identity of Marinus, since Neapolis was a Hellenistic city, and a Samaritan would never refer to Abraham as "the father of the old Hebrews." Cf. PUMMER (n. 58) 423-424.

${ }^{84}$ LifSHITZ, B. - SCHIBY, J.: Une synagogue samaritaine a Thessalonique. Revue Biblique 75 (1968) 368-378. On the date of the script see PURVIS, J. D.: The Paleography of the Samaritan Inscription from Thessalonica. BASOR 221 (1976) 121-123.

${ }^{85}$ The previous idea that the text is the Greek translation of the Samaritan Pentateuch's priestly blessing was challenged by Tov, E.: Inscription grecque d'origine samaritaine trouvée a Thessalonique. Revue Biblique 81 (1974) 394-399.

${ }^{86}$ Translation of R. PUMMER (n. 76) 134-177, esp. 149.

${ }^{87}$ IG XIV 336. On the date, see BRUGNONE, A.: Iscrizioni greche del Museo civico di Termini Imerese. Kokalos 20 (1974) 218-264, esp. 232-236.
} 
inscription of a column contains Samaritan Hebrew script with a quotation from Num 10:35: קומה יהוה ויפצו איב]יד (Rise up YHWH may [your] enemies be scattered). ${ }^{88}$ It could have been part of a monumental Samaritan building, perhaps a synagogue. Since no other ruins have remained, this is still a hypothesis. ${ }^{89}$ On the other hand, a literary source refers to the existence of a larger Samaritan community on the Island. In two letters to the bishops of Catania and Syracusa, Pope Gregory the Great intervened in cases concerning Samaritan slave owners. They were not allowed to circumcise their slaves, and their Christian slaves should be freed. ${ }^{90}$ The interest of the pope concerning these issues could refer to the relevance of the Samaritans in these cities in Sicily.

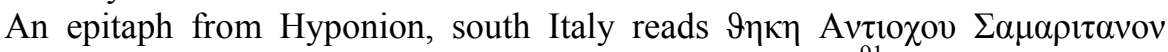
(sic!), though no further indication shows him to be a Samaritan. ${ }^{91}$

Josephus reported that during his stay in Rome Herod Agrippa I borrowed one

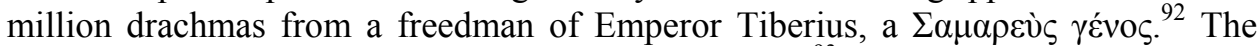
definition could mean either a Samarian or Samaritan, ${ }^{93}$ but testifies the presence of people from this region in Rome in the 1 st century CE. Samaritan presence in Rome is supposed by a confused discussion of Justin Martyr on Simon Magus' Samari(t)an followers. ${ }^{94}$ His text does not mention that these $\Sigma \alpha \mu \alpha \rho \varepsilon i \bar{\varsigma}$ worshipped Simon in Rome, but this act would be unimaginable of religious Samaritans anyway. Therefore Simon's followers were Samarians and not from Rome. ${ }^{95}$ Though the existence of a Samaritan community in Rome "may well have been the case, in view of the large number of Jews in Rome by that time", 96 the first real reference comes from the 6th century CE. The Roman statesman and writer, Cassiodorus mentioned a letter on the subject of the illegal purchasing of the Samaritan synagogue by Pope Simpicius:

It is represented to us by the Defensors of the 'sacrosanct' Roman Church that Pope Simplicius, of blessed memory, bought a house at Rome of Eufrasius the Acolyte, with all proper formalities, and that now the people of the Samaritan superstition, hardened in effrontery, allege that a synagogue of theirs was built on that site, and claim it accordingly; whereas $611-613$

${ }^{88}$ ORSI, P.: Gli scavi intorno a l'Athenaion di Siracvsa negli anni 1912-1917. Roma 1919, col.

${ }^{89} \mathrm{Cf}$. the discussion in Morabito, V.: The Samaritans in Sicily and the Inscription in a Probable Synagogue in Syracuse. In Crown, A. D. - DAVEY, L. (eds.): New Samaritan Studies of the SÉS. Essays in Honour of G.D. Sixdenier [Studies in Judaica 5]. Sydney 1995, 237-258, esp. 242-249.

${ }^{90}$ Lagumina, B. - Lagumina, G.: Codice diplomatico dei Giudei di Sicilia: Documenti per servire alla Storia di Sicilia Vol. I. Palermo 1884, VI 4-5. See also the discussion of MORABITO (n. 89) 237-239.

${ }^{91}$ Calabro, M.: Nuove scoperte. Notizie degli scavi di Antichità 10-12 (1921) 473-485, esp. 485. See the reservations of VAN DER HORST (n. 4) 251-260, esp. 255.

${ }^{92}$ Ant. 18. 167. The expression is preceded by a word questioned as an emendation by scholars. Cf. PUMMER (n. 36) 268-269.

${ }^{93}$ See the discussion of PUMMER (n. 36) 268-270.

${ }^{94}$ I Apol. 26. 2 and 56. 2.

${ }^{95}$ HALL, B.: Samaritan Religion from John Hyrcanus to Baba Rabba. Sydney 1987, 262-275. VAN DER HORST (n. 47) 140 denies this statement based on three reasons. See also PUMMER (n. 58) 22.

${ }^{96}$ VAN DER HORST (n. 47) 259. 
the very style of building, say their opponents, shows that this was meant as a private house and not as a synagogue. Enquire into this matter, and do justice accordingly. If we will not tolerate chicanery [calumniae] against men, much less will we against the Divinity Himself. ${ }^{97}$

This letter proves the existence of not only some Samaritans but also of a Samaritan synagogue in Rome, which indicates a larger Samaritan community in this city in late antiquity.

\section{THE ELUSIVE DIASPORA IN PERSIA}

The greatest revolt of the Samaritans against the Byzantine rule took place in $529 \mathrm{CE}$ under the reign of Justinian. Ioannes Malalas in his Chronographia tells that after the early Samaritan successes the Romans subdued the revolt by the help of an Arab chieftain (Saracen phylarch), Abu-Karib.

The Saracen phylarch of the Romans took 20000 boys and girls as booty from the Samaritans, he took them as prisoners and sold them in Persian and Indian territory. ${ }^{8}$

If these new slaves were really children, their Samaritan identity was hardly kept till they grew up. Therefore it is not probable that this group of young Samaritans formed any organized religious community in the East. Malalas refers to further contacts between Samaritans and Persians in the same period, and later Chosroes II conquered whole Palestine in $614 \mathrm{CE}$, but no migration is mentioned. ${ }^{99}$ In the west of Iran a Greek

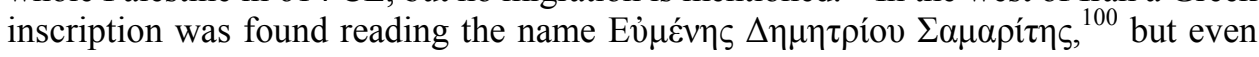
his ambiguous identity does not reinforce the reality of a Samaritan Diaspora in Persia.

A late diaspora of the Samaritans was founded in Damascus. This became the most important of all the previous Diasporas and existed between the 10th and 17th centuries. ${ }^{101}$

\section{CONCLUSION}

On the basis of this short survey we can assume that the formation of the Samaritan Diaspora at the different edges of Ancient Near East and Mediterraneum was caused

\footnotetext{
${ }^{97}$ Cassiodorus, Variae III 45. See the translation in http://www.gutenberg.org/files/18590/18590h/18590-h.htm\#CHAPTER_III.

${ }_{98}$ Malalas, Chronographia 18. 35. JEFFrey, E. et al.: The Chronicle of John Malalas. A Translation [Byzantina Australiensia 4]. Melbourne 1986, 261.

${ }_{99}$ Contra Crown (n. 4) 116. He refers to very modern Samaritan chronicles which confuse the story of Malalas.

${ }^{100}$ ROBERT - ROBERT (n. 73) 478.

${ }^{101}$ See Crown (n. 63) 215-217. Most extensively PUMmer, R.: The Samaritans in Damascus. In Bar-Asher, M. - Florentin, M. (eds.): Samaritan, Hebrew and Aramaic Studies Presented to Professor Abraham Tal. Jerusalem 2005, 53*-76*.
} 
by several factors. First of all, the military activity of the different empires and that of the Jews led to a forced migration. Here, two types can be named: the deportations or the settling of inhabitants into another land, and the selling of captives as slaves abroad. Another impact of the military activity was the need to take refuge in face of the impending danger or in face of a difficult economic situation. The incorporation of Palestine into a large empire raised the possibility of free traveling, for one's own economic interest, which was one clear cause of the migration of the community. A new and better life and work conditions, and the similar mobility of the Jews helped Samaritans to move to different places. This was not the globalization rather the "empirization" of Jews and Samaritans. Without the extension of the Hellenistic and Roman empires the Samaritans would not have moved so far. ${ }^{102}$

To sum up the problems of defining the Samaritan Diaspora, the small number of real sources has to be mentioned first. We have one Samaritan synagogue, two Samarian inscriptions and two Samaritan private documents. The second difficulty is the interpretation of the further primary and secondary data caused by the problematic Greek words for Samaritan. Not only due to the difference between Samarian and Samaritan, but also due to the rare usage in the early period, and the use of Hebrew, Israelite or Ioudaios instead. The third difficulty is that no history of a given Diaspora community can be sketched by the very sporadic data, consequently, only conjectures can be made. The conversion of Samaritans to Judaism and Christianity could have caused some discrepancies as well.

On the other hand, the decree of Justinian in 527 concerning the destruction of Samaritan synagogues and the prohibition of their rebuilding implies the wide scale existence of Samaritan synagogues and therefore Samaritan communities across the Roman Empire. Or as Van der Horst formulated: "Measures against Samaritans together with Jews, heretics and pagans makes clear that the legislators definitely did not regard the Samaritans as a 'quantité négligable', as an insignificant sect that was withering away somewhere in the corner of Palestine." ${ }^{, 103}$ The Samaritan Diaspora started sometime at the beginning of the Hellenistic rule in Palestine at the end of the 4th century, reached their widest geographical extent and numerical peak ${ }^{104}$ in Romano-Byzantine days, and ceased in the 17th century. Samaritans moved parallel with the Jews and their main centers were established where Jews were also present in significant quantity, but as Crown observed: "We may estimate a thousand in each of those places where there was a synagogue - and never more than perhaps threethousand in any centre. $" 105$

The destruction of the Gerizim temple enforced a slow but sure increase of a separate Samaritan identity which was noticed by Josephus at the end of the 1st cen-

\footnotetext{
102 "Famine, plaque and the devastating earthquakes of A.D. 549-550 must have seen many Samaritans anxious to leave their homeland and it is, perhaps, at this time that the Samaritan Diaspora in Arabia expanded..." CROWN (n. 63) 212.

${ }^{103}$ VAN DER HORST (n. 47) 142.

${ }^{104}$ CROWN (n. 4) 112.

${ }^{105}$ Crown (n. 4) 118. I do not agree with Crown's idea that the Samaritan Diaspora in Persia was as important as in Egypt.
}

Acta Ant. Hung. 56, 2016 
tury as follows: "they were determined to keep alive their fathers' way of life and customs." (Ant. 12. 10) These customs distinguished Samaritans from Jews at that time but in a way that does not help us today to point at their separate existence at all the places they were present in the Hellenistic and Roman empires.

József Zsengellér

Faculty of Theology

Károli Gáspár University of the Reformed Church

Budapest, Hungary

zsengeller@t-online.hu 